\title{
A crítica social do teatro da juventude de Dias Gomes em Eu acuso o céu (1943)
}

\author{
The social criticism in Dias Gomes youth theatre: \\ Eu acuso o céu (1943)
}

\author{
Alexandre Flory* \\ (D) https:// orcid.org/0000-0003-3435-458X \\ Marcio da Silva Oliveira* \\ (D) http:// orcid.org/0000-0002-0110-5635
}

Recebido em: 27/09/2018

Aceito para publicação em: 16/11/2018

RESUMO: A atividade teatral de Dias Gomes vai dos anos 1940 aos anos 1980. No entanto, ele costuma ser estudado a partir do sucesso de $O$ pagador de promessas (1960). Isso faz com que sua contribuição para o início da modernização do teatro brasileiro nos anos 1940 permaneça pouco estudada. Nessa época Dias Gomes, apesar de escrever para um dos atores mais famosos da época, Procópio Ferreira, trazia temas sociais em chave crítica como a questão do negro na sociedade, o nazismo, a situação terrível dos retirantes do sertão. Neste artigo pretendemos traçar um panorama dessa produção de Dias Gomes, sem nos esquivar de suas contradições, em especial pela análise de Eu acuso o céu.

Palavras-chave: Teatro brasileiro. Еu acuso o сéu. Dias Gomes. teatro e sociedade

ABSTRACT: The theatre activity of Dias Gomes has its beginning in the 1940s and lasts until the 1980s. However, the studies about his work normally consider the start of it with O Pagador de Promessas (1960). This way, Dias Gomes contribution to the modernization of Brazilian theatre in the 1940s remains less studied. At that time, Dias Gomes, despite of writing to one of the most famous actors of that time, Procópio Ferreira, brought social themes to discussion in a critical way, raising subjects as issues of black people in society, the Nazism, the terrible situation of the northeast migrants. In this paper we intend to delineate an overview of Dias Gomes production, specially through the analysis of Eu acuso o céu.

Keywords: Brazilian theatre; Eu acuso o céu. Dias Gomes. theatre and society

\section{Introdução}

\footnotetext{
* Professor Associado do DTL - Departamento de Teorias Linguísticas e Literárias da UEM Universidade Estadual de Maringá. E-mail: alexandre_flory@yahoo.com.br.

* Professor Doutor da Faculdade Santa Maria da Glória. E-mail: prof.marcioliveira2015@gmail.com.
} 
Dias Gomes é um dos autores mais importantes da dramaturgia (e da teledramaturgia) brasileira, autor de obras conhecidas e com grande repercussão. No caso do teatro brasileiro, infelizmente tão pouco estudado no campo dos estudos literários, conseguiu se tornar um dos poucos autores a romper com o silêncio crítico, muito por conta de seu sucesso televisivo. Porém, as peças da juventude, escritas (e, na maioria das vezes, encenadas) a partir dos anos 1930, recebem muito pouca atenção, como notamos mesmo em obra de referência como as de Costa (2017) e Rosenfeld (1996). Quando recebem atenção, como no caso de Mercado (1994), a perspectiva é antes a da recuperação cronológica do que a da avaliação crítica - o que não desmerece o projeto de publicação de boa parte de suas peças, antes o qualifica. Sendo assim, o desenvolvimento teatral a partir dos anos 1930 e, sobretudo, dos anos 1940 para o teatro brasileiro, não é levado em conta a partir das forças que estavam atuando para a modernização do teatro brasileiro. Podemos identificar como parte desse processo autores como Joracy Camargo, com seu Deus the pague (1932), que recebe uma paródia de Gomes em Pé de cabra (1942), ambas encenadas com sucesso por Procópio Ferreira, bem como grupos como o TEB (Teatro do Estudante do Brasil), organizado por Paschoal Carlos Magno a partir de 1938, e o TEN (Teatro Experimental do Negro), de Abdias do Nascimento (1944), e ainda Os comediantes (1938) que, em 1943, foram dirigidos por Ziembinski em Vestido de Noiva, de Nelson Rodrigues. Dias Gomes, embora não estivesse ligado a esses grupos amadores - que tinham liberdade para encenar obras experimentais fundamentais para o desenvolvimento de nosso teatro - não estava alheio ao contexto de mudanças. Embora escrevesse peças para Procópio Ferreira, autor de maior sucesso e representante máximo do assim chamado "teatrão", calcados na figura do primeiro ator e de uma estrutura batida e bem conhecida por todos, trazia temas que foram rejeitados (sobre o nazismo, sobre os retirantes) ou alterados (questão do negro, substituído pelo pobre) por Ferreira e/ ou pela censura. Isso o coloca em meio a uma contradição que lhe custou bastante caro, em termos estéticos: era preciso se submeter a um teatro totalmente voltado para o mercado, enquanto seus interesses pela crítica social e por uma arte de algum modo engajado o levavam a outros desafios.

O recorte que pretendemos realizar nesse artigo diz respeito à sua produção na década de 1940, mais especificamente com a peça Eu acuso o céu, de 1943, e tem o objetivo de demonstrar como, já nesse período inicial de produção teatral, Dias Gomes tematiza no teatro brasileiro a necessidade de inclusão social, seja do negro, do retirante ou de outras figuras situadas à margem social. Seu teatro desse período, embora encenado por companhias conservadoras, estabelece um pertinente diálogo com os grupos amadores, que propunham discussões históricas que levassem para o centro do palco a relação entre literatura e sociedade. Assim, mesmo inserido num contexto marcado pelo teatro profissional já ultrapassado, sua preocupação social afeita à problematização da exclusão social, fornece elementos para o debate a respeito do papel social da arte cuja revisitação, diante do momento histórico conturbado que nos encontramos, torna-se imprescindível. $\mathrm{O}$ teatro da juventude de Dias Gomes na história do teatro brasileiro 
No final da década de 1930, o teatro brasileiro não havia conseguido levar aos palcos um teatro e uma dramaturgia à altura do que o modernismo havia feito em outras artes. Ainda dominado pelo profissionalismo que se voltava para uma arte meramente comercial, ele se afastava de pretensões inovadoras e da apropriação histórica de discussões estéticas e sociais do período, sendo classificado apenas como diversão popular:

[...] o teatro comercial do final da década de 1930 nada dissera sobre a vida brasileira, não conseguindo passar adiante, como almejara certo momento, as mensagens revolucionárias de Marx e Freud; e, sobretudo, não soubera incorporar as novas tendências literárias (nem a ópera de Mário de Andrade, nem as peças de Oswald de Andrade foram encenadas em vida de seus autores), como já vinha acontecendo de um modo ou de outro com a poesia e com o romance. [...] Preocupações de ordem social ou moral perturbavam vez ou outra a tranquilidade dos conflitos familiares. Mas não se tocara no essencial, na maneira do teatro considerar-se, em si mesmo e em suas relações com o público. (PRADO, 1988, p. 36-37).

O teatro precisava, naquele momento, para se articular com a arte modernista de vanguarda nacional, desvencilhar-se desse mecanismo profissional marcado pela busca do espetáculo comercial e, por outro lado, atingir novos públicos, manifestar uma prática estética de cunho social, comprometida com seu momento histórico. Para isso, era preciso quebrar a mesmice dos métodos cênicos, com suas cristalizadas rotinas de trabalho, com a subserviência do artista frente à bilheteria, com a repetição de fórmulas superficiais e sem a preocupação com a crítica social. Em suma, o teatro precisava livrar-se da superficialidade que o mantinha em um estado agônico. O caminho encontrado foi a busca por novos públicos, à margem da cena teatral dominante:

Para salvar o teatro, urgia mudar-lhe as bases, atribuir-lhe novos objetivos, propor ao público - um público que se tinha de formar - um novo pacto: o teatro enquanto arte, não enquanto divertimento. [...] grupos de vanguarda que não encontram saída a não ser à margem dos palcos oficiais, tendo sobre estes a vantagem de não necessitar tanto da bilheteria para sobreviver. (PRADO, 1988, p. 38).

Inicia-se um período em que a salvação do teatro enquanto manifestação estética depende da busca pelo marginal, pelo amadorismo distante do chamado teatro comercial. Tal movimento só poderia ser engendrado por pessoas cujos objetivos concentrassem esses esforços. $\mathrm{O}$ sentido do teatro amador de grupos como Os Comediantes, GTE (Grupo de Teatro Experimental, 1942), GUT (Grupo Universitário de Teatro, 1943), TPA (Teatro Popular de Arte, 1948), TEN (1944), TAP (Teatro de Amadores de Pernambuco, 1941), TEP (Teatro do Estudante de 
Pernambuco, 1940), entre outros, traz novos e favoráveis ares para a dramaturgia e para a cena nacionais. Esses grupos, guardadas suas enormes diferenças, mantinham em suas propostas a firme convicção de que poderiam transformar o teatro, delegando para si a tarefa de reforma estética do espetáculo, procurando incorporar o gênero às teorias de vanguarda artística existentes nas outras artes. Trata-se de um esforço coletivo de um momento histórico, pavimentando caminhos que seriam percorridos mais tarde por escritores como Jorge Andrade e que, também, ajudariam Dias Gomes a abandonar a proposta de teatro comercial de Procópio e dedicar-se ao desenvolvimento de outros projetos.

Para Magaldi, "a maioria da crítica e dos intelectuais concorda em datar do aparecimento do grupo Os Comediantes, no Rio de Janeiro, o início do bom teatro contemporâneo no Brasil." (MAGALDI, 2004, p. 207). Para essa crítica, até esse momento, o que se via no teatro na década de 1930 eram apenas esboços ou tentativas isoladas de se buscar possibilidades estéticas, mas, com o início de 1940, presencia-se o nascimento de uma proposta realmente efetiva de revolução artística. É por isso que Magaldi atribui à formação do grupo uma grande importância na cênica nacional, chegando mesmo a afirmar: "Está fora de dúvida: pelo alcance, pela repercussão, pela continuidade e pela influência no meio Os comediantes fazem jus a esse privilégio histórico." (MAGALDI, 2004, p. 207).

Mas não podemos cair no erro de julgar o papel de Os comediantes como se eles dirigissem ou indicassem os caminhos para o teatro brasileiro, com um esforço individual e visionário. Será melhor apontar o processo histórico visto faz pouco, bem mais amplo, e entender Os comediantes como um momento representativo de um percurso maior e heterogêneo. Afinal de contas, também a historiografia precisa de métodos menos centrados em esforços isolados, que normalmente se afastam da complexidade da vida social e dos movimentos artísticos. Como vimos, é preciso muita atenção a cada passo para não cair no engodo de uma história teatral que precise de protagonistas individuais, identificáveis e idealizados.

Nesse momento de transição, Dias Gomes escrevia sua segunda peça: "um drama antinazista em três atos que já revela o pendor pela teatralização de temas momentosos da atualidade histórica: na peça são abordados o nazismo, a invasão da França pelos alemães, o exílio dos perseguidos políticos nos países da América..." (MERCADO, 1994, p. 21-22). Trata-se de Amanhã será outro dia, que em 1941 foi levada às mãos do ator Procópio Ferreira, que ficou bastante empolgado com o escritor iniciante. Ator e empresário, Procópio Ferreira é destacado como símbolo de uma época em que o principal objetivo do teatro era o divertimento. Para ele escreveram dramaturgos como Viriato Correa, Joracy Camargo, Dias Gomes, entre outros. Sobre o ator, Décio de Almeida Prado escreve:

[...] por quase três décadas ele reinara inconteste - o ator mais engraçado de um teatro que se queria unicamente cômico. Recebera inclusive a mais alta homenagem prestada aos seus grandes homens pela opinião brasileira - perdera o sobrenome. Quando se falava em Procópio, ninguém tinha dúvidas de que se tratava naturalmente de Procópio Ferreira. Pois eis que de repente chegávamos nós, com outras idéias, outros métodos, outra dicção cênica, outra concepção de teatro. No mesmo ano - 1948 - em que 
ele fazia cinquenta, inaugurava-se, fruto de um decênio de esforço amador, o TBC. [...] Tudo o afastava, no entanto, do teatro moderno, desde a obrigação de decorar o papel até a idéia ridícula de que o ator necessitava de alguém - o encenador - para o guiar na criação do papel. Ele se fizera no palco e ao contato com o público, os únicos mestres que reconhecia como legítimos. (PRADO, 1993, p. 43-44).

Dias Gomes, priorizando Procópio, com sua estrutura como teatro profissional e oposto à modernização buscada pelos grupos amadores, acaba por se adequar, em suas primeiras peças, ao sistema do ator/empresário, ou seja, ao que havia de mais ultrapassado, mas que fazia grande sucesso junto ao público. Isso denota seus objetivos que, nesse momento, se pautavam pela busca de estabilidade financeira, o que só poderia advir de fórmulas prontamente aceitas pelo público. Entretanto, seus temas não deixavam de ser caros para os grupos que buscavam novos caminhos, como é o caso de Amanhã será outro dia, entregue e prontamente recusada por Procópio.

Embora tenha gostado do texto de Gomes, o ator e empresário resolveu não encená-lo por achar demasiado arriscada a representação de um drama antinazista em plena Segunda Guerra Mundial, num contexto em que o Brasil ainda não havia se posicionado claramente (Getúlio Vargas, como se sabe, inclinava-se pelo nazismo nos primeiros movimentos da guerra). Na peça, Dias Gomes já esboça características que o acompanharão durante toda sua trajetória como escritor, principalmente a forte carga social e política dos personagens, analisados de acordo com o momento histórico em que vivem. Nela se percebe que o caminho trilhado (a problematização histórica e social) apresenta relação com os propósitos modernizantes dos grupos amadores que se formavam, tanto assim que foi prontamente recusada por Procópio e por Jayme Costa.

Convém destacar, no entanto, que Dias Gomes também diverge da concepção de teatro moderno com a qual Magaldi identificou Vestido de noiva, de Nelson Rodrigues, encenada em 1943 pelo grupo Os comediantes sob a direção do polonês Ziembinski, com enorme sucesso de público e de crítica. É importante frisar isso para se perceber que não havia apenas dois caminhos, o antigo e o moderno, mas um contexto bem mais variado. Gomes apresenta a situação política e os problemas sociais do país sob a ditadura do Estado Novo (1937-45), coloca em cena os desdobramentos da $2^{\mathrm{a}}$ Guerra, ainda em andamento, tematiza pobres retirantes do nordeste brasileiro, enquanto Nelson Rodrigues se desenvolve no terreno da ambientação psicológica, do mergulho em indivíduos específicos, sem menção ao momento histórico ou a problemas sociais, e especialmente sem confrontar ou problematizar o cenário burguês no qual insere o assunto desta peça. Sendo assim, a atuação de Dias Gomes no contexto da modernização do teatro brasileiro é bem diferente, poderíamos dizer até que está em oposição, à perspectiva de Nelson Rodrigues - ambas válidas e importantes.

O teatro de Nelson Rodrigues trabalha nas entranhas nada sadias do mundo burguês, identificando seus vazios e pontos-cego, suas contradições, para gozar com elas - como se as ambiguidades e falsidades referentes ao quadro burguês fossem universais e absolutas. Uma análise de sua obra que não leve em 
consideração as neuroses e obsessões burguesas torna-se quase desprovida de sentido, mas isso não é feito em função de uma mudança. A construção moral severa e hipócrita do mundo no qual suas peças transitam, influenciada essencialmente pela ideologia religiosa da 'família', acaba por gerar uma espécie de sombra, de válvula de escape e que desencadeia, na obra de Rodrigues, o distanciamento das virtudes burguesas. Assim, ele fala de situações e neuroses inescapáveis que habitam o 'submundo' de um universo castrador. Através de sua crítica - que mostra uma sociedade disfuncional, cheia de neuroses e psicopatologias que desencadeiam taras e perversões levadas, inclusive, ao limite do cômico, - ele efetivamente expõe a crise do mundo burguês, mas não com o objetivo de superá-lo. Para realizar esse projeto, em termos estéticos, ele se aproxima do que Raymond Williams (2011) chama de "expressionismo subjetivo" (WILLIAMS, 2011, p. 82), de tal modo que uma frase de 1919 do expressionista Theodor Däubler cabe bem no projeto rodrigueano: "O nosso tempo tem um projeto grandioso: uma nova erupção da alma! O eu cria o mundo." (DÄUBLER apud WILLIAMS, 2011, p. 82).

Aqui está um ponto em que se pode estabelecer uma contraposição com a escrita de Dias Gomes: Nelson Rodrigues não faz crítica do mundo burguês por seus pressupostos fundadores e em seu funcionamento opressivo e injusto, localizando-o historicamente a fim de superá-lo. Ele simplesmente mostra o anverso da ordem e da moral vigentes, também realidades pulsantes, como uma dimensão inescapável da natureza humana. A perversão e obsessão de seus indivíduos não mira mostrá-lo, o indivíduo, como um constructo histórico e mutável. Apresenta-se o negativo do homem virtuoso, e se goza essa situação existencial, antes de expor sua falsificação. A ordem burguesa está mantida, intocada, como absoluta, incluindo suas 'estimulantes' sombras. Já Dias Gomes trabalha, de alguma forma e progressivamente, contra essa ordem vigente; a questão não está em somente detectar as perversões ou contradições relacionadas à burguesia, mas localizá-las historicamente para mostrar sua responsabilidade pela crise instaurada. Gomes trabalha prioritariamente, e progressivamente, com o tipo social, com o fruto do meio produzido por uma sociedade disfuncional e, para compreendê-lo, é necessário que se entenda o seu contexto histórico e, principalmente, a que situação social de opressão e exclusão social ele se liga. A linha remete antes ao naturalismo do século XIX, ao menos pela localização social das questões mais relevantes, do que ao expressionismo (subjetivo ou social) ou ao teatro épico. O registro realista permite que seja aceito por um empresário/ator como Procópio Ferreira, embora os temas já não pareçam caber nas formas dadas. Essa tensão contínua entre forma rígida e tema progressista irá marcar a obra de Dias Gomes, com grande vigor e visibilidade nas peças da juventude.

De início tímido, a busca formal e temática em função de um teatro político, engajado sem perder de vista a inovação estética para expressar seu caráter profundo, desmascarando mazelas sociais, torna-se projeto continuado na produção de Gomes. Tais aspectos, incluídos no contexto de nascimento de novas estéticas de representação cênica, o colocam como um dos pioneiros da revolução teatral da década de 1940 - embora sob a imensa contradição de fazê-lo a serviço do que havia de mais arcaico no teatro brasileiro. Sob o imperativo do 'fazer rir' e 
também motivado pela necessidade do 'drama social' iniciado por Deus lhe pague, de Joracy Camargo, Gomes estabelece um diálogo entre ambos e, assim, auxilia na reestruturação dramatúrgica no nascimento do moderno teatro nacional.

Outro exemplo interessante é a peça Doutor Ninguém (1943), que tinha como objetivo explorar a temática do problema racial e das desigualdades sociais e, por isso, colocou como personagem principal um médico negro e pobre que se apaixona por uma jovem rica. Ao tratar da temática racial (por sinal, rechaçada pela companhia de Procópio Ferreira, na qual a peça foi encenada com mudanças significativas), Gomes procura desnaturalizar a situação do negro em um país preconceituoso e explorador como o Brasil, que ainda hoje está distante de enfrentar social- e politicamente a opressiva situação dos negros no país. Nesse sentido, suas ideias estavam em consonância com a formação, no ano seguinte, em 1944, do Teatro Experimental do Negro (TEN), fundado por Abdias do Nascimento, cujo trabalho direcionado aos negros incluía alfabetização, iniciação à cultura e a consequente viabilização da formação para o teatro. No campo das artes cênicas, objetivava não somente criar possibilidades para a inserção do negro no mercado de trabalho, mas também propor uma mudança de paradigma na história do teatro nacional, composto por um público acostumado à esmagadora predominância de atores brancos, que se pintavam para representar papéis de personagens negros. Trata-se de um projeto, como vemos, de busca pela inclusão social e que é acompanhado de perto pela exploração temática de Dias Gomes. Para se ter uma ideia da dimensão das dificuldades enfrentadas, Procópio Ferreira transformou Doutor Ninguém em

melodrama banal quando a encenação eliminou sumariamente da peça a problemática do racismo (alegando que um médico negro como protagonista seria inaceitável para a platéia, Procópio mudou a cor do Dr. Crisóstomo, e o preconceito de cor virou preconceito de classe - a estória de um rapaz humilde, filho de pai desconhecido, que era por isso impedido de casar com uma moça rica. "Uma babaquice", recorda Dias Gomes. Um pobre gênio foi considerada inviável por apresentar um herói proletário e ter como tema uma greve operária; e Eu acuso o céu jamais chegou a ser encenada." (MERCADO, 1994, p. 34)

Devemos adiantar que Eu acuso o céu (1943) trata da seca do nordeste e da migração de retirantes para o litoral, oprimidos pela condição climática e pela pressão dos coronéis, para evidenciar quanto é variado o temário de Dias Gomes nessa sua produção da juventude. Seja o preconceito racial, a exploração proletária ou a miséria dos retirantes, temos um quadro social bastante amplo e significativo. Se lembrarmos que a encenação de Eles não usam Black-tie, de Guarnieri, em 1958 pelo Arena, é um marco por tratar da greve operária (como Um pobre gênio), percebemos a importância de revisitar essa produção de Dias Gomes pela perspectiva de jogar luzes sobre um quadro social desigual a partir dos que não têm voz, o que é reforçado pelas dificuldades (ou impossibilidades) efetivas para subir aos palcos. Isso apesar dessas peças terem sido escritas todas em 1943 como parte de um contrato assinado por Gomes com Ferreira para que fosse autor 
exclusivo de sua companhia, e que exigia a escrita de quatro peças anuais - cinco, se considerarmos que Procópio poderia recusar uma e Gomes ter que escrever outra para seu lugar. (MERCADO, 1994, p. 26) Além das três citadas a pouco, escreveu ainda, em 1943, João Cambão e Zeca Diabo, que foram encenadas.

Nessa primeira fase da dramaturgia de Dias Gomes encontra-se o embrião do que será sua produção posterior. A busca pelo desmascaramento e pela denúncia dos preconceitos, intolerâncias e desigualdades pavimenta os caminhos de engajamento político do escritor, manifesto através da arte teatral e de suas atividades político-partidárias no PCB. O retrato dos contrastes e conflitos da realidade brasileira, com temáticas de cunho social, está muito presente nas produções dessa sua primeira fase, embora essas ideias ainda se apresentem de modo superficial e difuso. Tais traços só ganharão profundidade a partir do início da década de 1960, com a publicação e apresentação de O Pagador de promessas.

\section{Considerações sobre a peça Eu acuso o céu (1943)}

Dividida em três atos e seis quadros, a peça trata de uma família nordestina que, em consequência da seca que devora sua lavoura e da apropriação indevida de suas terras por um coronel e seus jagunços, se vê obrigada a migrar para o litoral, não em busca de melhor qualidade de vida, mas de mera sobrevivência. No primeiro ato, estão no norte da Bahia, em uma plantação de fumo. Nesse espaço temos os dois primeiros quadros. No primeiro, Anselmo aparece na casa do camponês Jerônimo e de seus filhos Liana e Pedro. Ele está vindo de uma região da Bahia onde a seca já se estabeleceu, enquanto no sítio de Jerônimo ainda há água, frutas, verduras. Mas Anselmo veio de mais longe: ele é pescador e veio do litoral, que abandonou após seu barco saveiro virar e perder esposa e filha. Porém, ao enfrentar a seca profunda do sertão, tem saudades cada vez maiores do litoral e do mar. No segundo quadro, passou tempo suficiente para que a seca tenha se instalado completamente. Não há água nem nenhum sinal de vida, fora a família e Anselmo que lutam bravamente. Nesse momento surge o Coronel, cobrando o empréstimo que Jerônimo fizera para plantar - e que seria pago com a colheita. $O$ Coronel exige que o pagamento, então, seja feito com o sítio de Jerônimo, embora tenha prometido que não tomaria suas terras. A situação, que já era terrível, tornase insustentável e a família aceita a proposta de ir para o litoral com Anselmo.

No segundo ato, o terceiro quadro se inicia com a apresentação de duas novas personagens: Rosa e Raimundo, respectivamente irmã e sobrinho de Anselmo. Esse quadro é marcado pela declaração de amor de Raimundo para Liana, que provoca ciúmes em Anselmo - que, apesar de mais velho, por volta dos 45 anos, estava criando coragem para se declarar à jovem de 25 . O quarto quadro ocorre imediatamente após o final do terceiro: embora venha uma tempestade, Anselmo vai ao mar e leva consigo Jerônimo e Pedro, em grande medida porque ficou estarrecido em perceber que Raimundo e Liana se querem. Nessa saída, ocorre o naufrágio do saveiro, e Pedro fica entre a vida e a morte; o quadro termina em aberto, sem que saibamos o que ocorrerá com Pedro. 
O terceiro ato (e quinto quadro) salta para algum tempo depois, quando Pedro já está restabelecido e Anselmo entregue à bebida e à prostração. Liana e Raimundo tratam abertamente de seu casamento. Nesse momento, surge Liana com a notícia de que choveu no sertão, e que muitos retirantes já voltam para suas casas. Resolvem voltar no dia seguinte à sua terra, mesmo agora não tendo mais o sítio, que intentam reaver. No sexto e último quadro, Raimundo prepara sua trouxa porque decidiu acompanhar a família para se casar com Liana. Nesse quadro, aparam-se as arestas seja entre os homens, seja dos homens com as forças da natureza. A chuva trouxe de volta a vida, e aos poucos Liana pede desculpa a Anselmo por tê-lo tratado mal - ela sempre rejeitou o projeto acalentado e insuflado por Anselmo de vir para o litoral. Anselmo sente-se aliviado, pois percebe que, enquanto a família de Jerônimo estivesse no litoral, ele se sentiria oprimido por tê-los tirado de seu lugar no mundo. Aos poucos, mesmo o amor que sente por Liana se transforma em uma espécie de amor filial, e portanto apaziguador. No final, Anselmo, Liana, Rosa e todos estão tocados por bons sentimentos e por uma profunda esperança - o que destoa, e muito, do quadro inicial, e será discutido mais adiante.

Trata-se de personagens simples, que não buscam demonstrar qualquer tipo de engajamento político ou ideológico, pois têm como único objetivo sobreviver, o que beira o impossível em ambiente inóspito e desolador:

[...] acho que dessa vez a gente não aguenta, não. Parece maldição. Tem vez que eu não me conformo... Não posso vê essa miséria toda. E o que foi que a gente fez pra merecê isso?! [...] A gente vê o gado mugindo, mugindo de fome, de sede, fuçando o chão, farejando água, té caí sem força... sem força nem pra mugi! A plantação inteira morre, tudo morre. Só por causa da água, da água! (GOMES, 1994, p. 167).

O sofrimento que desencadeia certo desabafo em relação ao martírio em que vive a família se articula na sequência da peça ao respeito pela terra, à crença em dias melhores e no amparo do divino para que possam suportar o flagelo da seca. Nesse sentido, a peça adota um registro popular pouco usual no teatro da época, numa linguagem que mostra até mesmo o modo como o dramaturgo propõe uma espécie de poética da fome. Primeiramente, só poderia ter sido escrita por alguém advindo do espaço do sertão ou que tenha estabelecido um contato profundo com o Nordeste. Mesmo passando boa parte de sua vida no Rio de Janeiro, Dias Gomes insere o sertão nordestino como conteúdo fundamental para a criação de seu teatro popular, que se localiza historicamente e visa apresentar o modo como se dá a exploração em âmbito nacional.

Em Eu acuso o céu, uma das discussões centrais está na luta dos retirantes pela posse de uma terra que nada vale, mas que os mantêm dispostos a enfrentar o coronelismo na esperança constante de, mais dia menos dia, conseguirem sustentar algum roçado: "não adianta tê esperança porque a chuva não vem mesmo tão cedo. Mas também a gente não vai fugi que nem galinha. A gente finge que tem esperança, reza, faz mandinga e güenta firme." (GOMES, 1994, p. 169). A decisão de abandonar a terra e partir para outro espaço só aparece quando, 
forçados pela violência, são expulsos e vão para o litoral, experimentando outro tipo de flagelo e sempre na esperança da chuva para retornar às suas terras. $\mathrm{Na}$ viagem da família para o litoral, acompanhada pelo forasteiro Anselmo, o texto se volta a estabelecer de modo objetivo, mesmo que pautado por certo lirismo, a relação dos personagens com o espaço geográfico. Ele trabalha sobre o contraste entre terra e mar, que se reveste não da universalização desses espaços, mas das contradições da realidade brasileira e da solidariedade na miséria, muito comum entre as camadas marginalizadas.

Sendo assim, em Eu acuso o céu, Gomes enfoca a temática da seca nordestina e, em consequência, da migração desenfreada dos retirantes para o litoral em busca de melhores condições de vida, como visto. Além disso, o texto denuncia a incorporação ilegal de terra por parte dos grandes proprietários, mantendo as vítimas dos flagelos da seca em situação ainda mais desesperadora, como destacado no trecho abaixo:

JERÔNIMO: Então, seu Coroné, me disculpe mas nós não temo com que pagá.

CORONEL: Não têm? E esse sítio?

JERÔNIMO: Esse sítio? Mas esse sítio é nosso.

CORONEL: Então? Se é de vocês, tem com que pagar.

ANSELMO: O senhô não pode fazê isso!

CORONEL (mordaz e ameaçador): E por quê?

ANSELMO: Porque não é justo!

PEDRO: O senhô deu sua palavra...

CORONEL: Não dei palavra nenhuma.

ANSELMO: Mas prometeu adiá a cobrança.

CORONEL: Isso é outra coisa. Prometi, mas mudei de idéia. Pronto.

ANSELMO: O senhô não pode tomá a terra deles, assim, sem mais nem menos.

CORONEL: Não posso?! Então eu não posso cobrar o que eles me devem?

ANSELMO: Mas eles prometeram lhe pagá com a safra.

CORONEL: E cadê a safra?

ANSELMO: A seca estragou.

CORONEL: Então eles têm que pagar de qualquer outro modo.

ANSELMO: Não é direito, é uma injustiça!

CORONEL: Olha, moço, a justiça aqui quem faz é o mais forte, ouviu?

JAGUNÇO (adiantando-se, ameaçador): É bom não se esquecê disso. CORONEL: Tem dois dias para sair daqui. Por bem. A menos que prefiram sair por mal.

LIANA: O senhô tem tanta terra, por que precisa da nossa?

CORONEL: Isso é cá comigo. (GOMES, 1994, p. 174-176).

A temática adotada por Dias Gomes na peça assumia, como destacado no trecho acima, um caráter de denúncia social relacionada à opressão do homem pelo homem, à exclusão manifesta no constante dilaceramento identitário dos retirantes expostos, ao mesmo tempo, às catástrofes naturais e àqueles que se nutrem de suas 
misérias. Tal situação não foi bem aceita pelos empresários da época e, por isso, a peça também não foi encenada. Merece destaque inicial a linguagem (e a prosódia) coloquial dos pequenos agricultores, em contraste direto com a linguagem culta dos donos do poder. Em verdade, essa linguagem culta não escamoteia a violência e prepotência que materializa: “Tem dois dias para sair daqui. Por bem. A menos que prefiram sair por mal."

Os pequenos lavradores, que dependem da ajuda do coronel para plantar, ficam à mercê de suas arbitrariedades, o que fica claro quando diz: "Prometi, mas mudei de idéia". O que parece, à primeira vista, apenas capricho que é típico de uma elite que despreza os que explora, é também cálculo e projeto de expropriação: ele exige como garantia a terra, único bem dos camponeses, dizendo que não executará a garantia sob hipótese alguma, mentindo amizade; assim que a situação se apresenta favorável, usa de todos os meios para extorquir o máximo dos que pouco ou nada têm. Soma-se à miséria do lugar o abuso dos coronéis e a falta de toda e qualquer ajuda do governo, o grande ausente dessa equação que resulta no aumento da desigualdade e em várias formas de sujeição abjeta.

Essa dimensão histórica do abuso e exploração das nossas elites é uma das linhas de força da peça, embora, a julgar pelo título da peça, o ocaso dos retirantes se deveria ao destino, aos céus, ao plano divino. De fato, essa é uma das questões centrais da peça, pois a submissão passa pela falta de consciência do lugar social da desigualdade - apesar do abuso, não há a quem recorrer, e se aceita o roubo explícito. Deste modo, enquanto os personagens, envoltos em suas tragédias pessoais, vivem num determinado espaço, para a estrutura da peça, e para o seu discurso e significação, o espaço físico e social atua como personagem, determinando a situação de miséria. Essa determinação é, sobretudo, histórica, pois tem a ver com a apropriação de enormes latifúndios improdutivos sem qualquer mediação do Estado para dar terra e o mínimo para o trabalho e a sobrevivência dos que lá vivem.

Sendo assim, a peça trabalha em duas frentes: por um lado, temos o horizonte limitado dos personagens, que não percebem a falta de consciência crítica que o processo de aniquilamento produz, e culpa alguma instância metafísica - quando não culpa a falta de vontade para trabalhar ou a falta de competência, com o que reproduzem a falsidade da meritocracia burguesa e do sucesso como resultado do esforço e capacidade individuais. Por outro lado, a peça, ainda que timidamente (não estamos no teatro épico de matriz brechtiana, que pediria por uma explicitação dos mecanismos para o público), indica o engano dessa leitura, como se percebe por esse pequeno excerto. Os espaços físico e social deixam de ser apenas uma referência de localização e, a partir de dinâmicas históricas e sociais mais amplas, tornam-se elementos fundamentais de uma determinação coletiva que está em jogo para criar os impasses e a impossibilidade de sucesso dos personagens, que se embatem contra as adversidades sem conseguir sair do lugar social em que estão. Estamos muito distantes, fica claro pela peça, do que Brecht (2007, p. 259) diz no poema Sobre a atitude crítica, escrito por volta de 1938: 
É para muitos não muito frutífera

Isso porque com sua crítica

Nada conseguem do Estado. Mas o que neste caso é atitude infrutífera

É apenas uma atitude fraca. Pena crítica armada

Estados podem ser esmagados.

A canalização de um rio

O enxerto de uma árvore

A educação de uma pessoa

A transformação de um Estado

Estes são exemplos de crítica frutífera.

E são também

Exemplos de arte.

O poema de Brecht ajuda a entender, por vários caminhos, que a atitude crítica efetiva, e performativa, não é científica, no sentido estrito do termo: objetiva, neutra, positivista. Ela precisa ter algum sentido humano e estético. É um fazer, não apenas um acúmulo de conhecimento técnico vazio. Está tanto na canalização de um rio quanto no enxerto de uma árvore, que contribuem para a construção de um saber sobre a importância do fazer social. Esse é o caminho para a educação de um homem, de muitos homens, que assim podem cogitar mesmo a transformação do Estado. A arte faz parte desse processo, não apenas de modo derivado, mas integrado: esses fazeres são exemplos de arte. O sistema educacional brasileiro preza muito por impedir esse desenvolvimento humanista da razão não instrumental. Dias Gomes mostra que isso pode ser pensado, e elaborado esteticamente, mas como uma impossibilidade objetiva dadas as condições de nossa estrutura de poder e, daí, de organização social. Seria falso, social e esteticamente, resolver essa situação na peça, seja no tema seja na forma. Assim, a peça termina sem terminar - posto que os problemas se inserem em outros horizontes que não os subjetivos - o que configura nova ruptura com o teatro dramático, pois este exige conclusão. Nesse sentido, é importante frisar que Dias Gomes trabalha por quadros na peça, seis ao total - o que traz esse caráter inconcluso, fragmentário, para a forma da peça. Não é à toa que a peça não foi encenada por Procópio Ferreira, apenas transmitida radiofonicamente.

Infelizmente a peça não faz dessa perspectiva desenvolvida por Benjamin (1985) da 'dialética em suspensão' (entre o horizonte dos personagens e aquele da peça; entre o contingente e o conjuntural; entre o metafísico e o histórico), pois as menções à estrutura desigual são esparsas e superficiais, especialmente a partir do segundo ato, quando eles se mudam para o litoral. A partir daí, não há mais remissão a essa tensão constitutiva, que se resolve pela interação entre os personagens e por acusações contra a implacável tirania dos elementos naturais, seja o mar onde reina Iemanjá que requer seus mortos, seja a terra que esturrica os viventes. Além disso, a peça perde força e termina muito mal ao abandonar até mesmo essa dimensão da força terrível da natureza (que indica, ao menos, o abandono dos pobres personagens à sua própria sorte que, dada a situação social, não pode ser boa) e foca na disputa amorosa entre Mestre Anselmo e seu sobrinho 
Raimundo por Liana. Estes dois últimos se amam e resolvem se casar, gerando frustração e ciúmes em Anselmo, o que contribui para o acidente no qual Pedro (irmão de Liana) por muito pouco não sucumbe. Ao final, volta a chover no sertão, o que traz esperanças aos retirantes e leva ao seu retorno. Raimundo acompanha o grupo para se casar com Liana, deixando Anselmo, que em certa medida remoe suas dores, aceitando, paulatinamente, um papel de segundo pai de Liana. A fala de Anselmo quando os retirantes vão embora, após ser chamado de pai por Liana, é: "Que o diabo os carregue! (Caindo em si. Voltando-se, comovido.) Adeus, minha filha. [...]" (GOMES, 1994, p. 250). Logo depois, ameaça um temporal, e Anselmo resolve enfrentá-lo em seu saveiro. Nesse momento:

Anselmo: Mau? Que nada, isso é bom. Tu ainda não reparou que é a chuva e o vento que governa a vida da gente? Foi por causa da ventania que virou meu saveiro que eu perdi minha mulhé e minha filha e me embrenhei pelo sertão. Por falta de chuva no sertão foi que eu voltei e eles vieram comigo. E agora, porque tá chovendo lá, é que eles voltam. A terra e o mar não têm culpa nenhuma! A culpa é do vento e da chuva! Vem de cima!

Rosa: Do céu? (chove, reboam trovões. A tempestade desce, furiosa.)

Anselmo: É, do céu! A culpa é do céu! (Levanta-se. Apanha o chapéu de palha, dois remos)

Rosa: Pra onde tu vai, home?!

Anselmo: Pro mar.

Rosa: Com esse temporal?

Anselmo: Que tem isso? O lugá de um pescado é no leme do seu saveiro.

Rosa: Espera, também vou com você.

Anselmo: Então, vamo! Vamo desafiá o céu! (Saem os dois abraçados enquanto...)

Cai o pano

(GOMES, 1994, p. 251-2)

Neste final, Anselmo recobra suas forças e se ergue para enfrentar a suposta causa de seu infortúnio, em uma atitude do nível de um herói trágico que enfrenta seu maior desafio e aceita seu destino - ele, que esteve prostrado e quieto após o desastre que quase custou a vida de Pedro, causado por dores de amor. Seja ele e sua irmã Rosa, seja Jerônimo, Pedro, Liana e Raimundo, todos estão enfrentando as condições adversas como demanda individual e escatológica, reforçando as condicionantes subjetivas - há saída, mesmo que seja a morte, mas enfrentada com coragem e vontade férrea. Fica em segundo plano, portanto, o caráter não conclusivo do final: 1) eles saíram de suas terras quando o Coronel as tomou, e ao voltar nada terão; 2) a seca voltará em pouco tempo e a situação original estará reposta; 3) Raimundo é pescador e, como muito repisado na peça, em algum momento desejará voltar ao litoral. Isso se perde ante as questões subjetivas de Anselmo, Liana, Raimundo e demais. Assim, uma perspectiva apaziguadora e linear aos poucos assume a primazia do ponto de vista da peça. O drama social que se impunha no primeiro ato, com a riqueza dialética que propõe e já 
acompanhamos, acaba solapado e planificado pela subsunção ao teatro dramático, que se interessa por sujeitos autônomos que sabem o que querem e agem para tal - no caso, quase um melodrama, com enorme entrega sentimental, peripécia imotivada e final feliz (chuva, casamento, amor). A peripécia imotivada diz respeito à chuva no sertão que, como um Deus ex-machina, vem resolver todos os problemas dos personagens, vistos a partir da superfície - não de seu lugar social, que é a seca, fome, abandono e desprezo.

Como foi dito faz pouco, esse final silencia a linha do drama social, que consegue vislumbrar o inacabamento da peça no futuro absolutamente incerto dos personagens, mas nem eles (o que é compreensível) nem a peça (o que é lamentável) deixam essa perspectiva aflorar e se sedimentar como decisiva. Ela esteve em primeiro plano durante o primeiro ato, foi dominante, mas perdeu-se e termina esquecida. Não se discute o enorme potencial do aceno ao drama social (com seus tipos) que Gomes apresenta, tensionando o drama psicológico de indivíduos bem marcados: Anselmo é pescador, mas não se resume a um tipo social, haja vista suas dúvidas psicológicas apresentadas ao longo da peça. Liana é uma retirante e, também, uma mulher sensível, forte e decidida, pronta para o trabalho, para a luta e para o amor.

Porém, a efetivação desse drama social em Gomes não se dá como, onze anos depois, em 1954, veremos em A moratória, de Jorge Andrade, encenada no TMDC (Teatro Maria Della Costa). Em Andrade (1986), surge uma perspectiva dialética e crítica entre os dois planos do personagem: Joaquim é um tipo (o patriarca senhor de terras), mas também uma psicologia única, especialmente pelo modo como trata a filha. Com isso, procura-se tanto a identificação e empatia com o personagem (visto de perto em suas angústias, como ser humano único) como a distância provocada pelo tipo social (enquanto patriarca, é rígido, inflexível e tacanho). A peça $A$ moratória trabalha com nuances dialéticas: não quer a idealização do mundo dos barões do Café, nem fazer contra ele um ataque frontal; não idealiza nem destrói também o novo contexto industrial citadino, em que Lucília sustenta a família trabalhando sem descanso sob o ritmo alucinante da máquina de costura. Lucília é tanto a filha criada para ser bem casada no seio da aristocracia (daí aprender a tocar piano e a fazer costura) como, também, uma personagem que aceita e se reinventa para estar à altura do novo quadro social, no qual se torna costureira e sustenta a família com seu trabalho, com orgulho e coragem suficientes para se contrapor às determinações paternas. A construção complexa desses personagens, que são indivíduos e tipos, subjetividades e discursos sociais, é decisiva para o ponto de vista crítico da peça, que mostra como esses discursos são construídos historicamente - daí se localizar justamente nos anos da crise, de 1929 a 1932, como época de transição, propícia para seu projeto.

Já na peça de Gomes aqui em tela, os personagens ora representam tipos, ora indivíduos, mas não parece haver uma estrutura para dar sentido a essa dupla articulação. Quando há denúncia social, estamos no campo do tipo. Quando o tema é o trabalho, o amor, a virtude, estamos às voltas com indivíduos. Essa é mais uma fragilidade da peça - a primeira é a sua planificação a drama. Como se viu, a peça termina com indivíduos retornando para sua terra. Assim, o que em A moratória é força dialética entranhada na forma, em Eu acuso o céu se limita ao plano temático, 
do conteúdo, e ainda assim sem grande produtividade. O interesse pelo social não consegue romper a barreira da forma dada, quase uma fôrma, ou uma fórmula. $\mathrm{O}$ início promissor, que remete ao que de melhor se tem na tradição do naturalismo - a essa altura, em 1943, muito pouco conhecida no Brasil, diga-se de passagem não se sustenta ao longo da peça, que recai em naturalização da miséria (culpa do céu) e, depois, em espaço para o exercício das virtudes de indivíduos que acreditam em si mesmos. Como essa transição é paulatina, porém objetiva dentro da peça, quase não percebemos a mudança profunda operada nela, que termina de modo conservador.

Podemos cogitar se a inflexão se deve ao conhecimento dos procedimentos que seriam aceitos por Procópio Ferreira, dono dos direitos do texto e de sua possível encenação, ou se se trata de falta de maturidade do autor, ou até mesmo as duas coisas. O fato é que, mesmo com essa amenização final em favor da conciliação, a peça foi rejeitada por Procópio Ferreira, e só foi encenada radiofonicamente, o que nos permite inferir que Gomes sabia (ou ao menos intuía) os limites a que estava constrangido. Evidentemente, essas críticas não pretendem diminuir a importância da dramaturgia gomiana, nem justificar suas fraquezas, pois já é um avanço, nos idos de 1943, ter conseguido tangenciar, e mesmo tocar, questões tão significativas. Mas é preciso acúmulo crítico, prático e teórico para que o teatro brasileiro se modernize, e aqui estamos, com certeza, numa das etapas mais importantes, porém iniciais, do processo.

\section{Considerações Finais}

Como vimos, a peça remete à situação política que mantém os retirantes em constante deslocamento para fugir do flagelo, sempre em busca de espaços que garantam sua subsistência (a volta da chuva, o acalmar da tempestade) em um país marcado pelo descaso do poder público e pela opressão dos detentores do capital. Acusar a violência que 'vem de cima' é desvelar a injustiça política, camuflada em fatalidade da natureza. Esses assuntos serão desenvolvidos com maior conhecimento de causa e perspectiva de encenação em peças posteriores, tais como A invasão e $O$ pagador de promessas.

Além disso, é evidente no contexto da peça que, ao falar de Jerônimo, Liana, Pedro, Anselmo, Rosa ou Raimundo, o dramaturgo não está focalizando apenas suas vivências individuais diante de uma situação de crise. Claro que, dada a necessidade dramática do período, o leitor é convidado a acompanhar certas individualizações, como a história de Anselmo e Rosa e os seus traumas com o mar. Entretanto, constrói-se, através deles, o flagelo de um grupo social obrigado a permanecer numa espécie de entrelugar, emigrando de um lado para outro em busca de migalhas para a sobrevivência, obrigados a viverem como forasteiros e sempre nutrindo a esperança de retorno a uma pátria devastada. Essa ideia de pertencimento fragmenta-se no decorrer da peça, como também são fragmentados todos os personagens que, mesmo tendo, de certo modo, seus conflitos subjetivos, ainda são mostrados como o retirante, o pescador, a viúva que perde o marido para Iemanjá, o trabalhador que sofre abuso do dono das terras, a vítima do flagelo da 
seca, o indivíduo miserável que se apega aos seus santos na esperança de dias melhores. As críticas apontadas não apagam essa perspectiva, embora a torne embaçada pelo desenvolvimento da peça, como se viu.

Ao final quando, excitada, Liana lê para os outros uma notícia de jornal, "com o fim da seca, os retirantes voltam às suas terras" (GOMES, 1994, p. 233), novamente a família se coloca em estado de deslocamento, agora nutridos de esperança pelo retorno a terra. No entanto, será mais uma jornada sem perspectiva: apesar de todo o derramamento subjetivo, resta aos leitores atentos identificar a certeza objetiva de que outros flagelos virão e, com eles, uma nova sensação de opressão e de não pertencimento - mesmo que isso deva ser feito contra a peça, que termina conciliadora.

Esse início turbulento de tentativas quase sempre frustradas de confronto com o sistema vigente levou Dias Gomes à busca de novas formas de comunicação. Para os críticos da época, as temáticas exploradas pelo dramaturgo esbarravam nas restrições drásticas do sistema político e, por isso, só poderiam ser aceitas em contexto não ditatorial.

Os outros achavam esses temas muito perigosos. E isso me levou a um desentendimento insolúvel, não só com Procópio, mas com todo teatro da época. E acabaria sendo o motivo do meu afastamento por vários anos. Eu me lembro uma vez, na porta do Teatro Dulcina, onde estava sendo encenado Zeca Diabo, Luciano, hoje o decano de nossos cenógrafos, me disse: "Menino, você está fazendo um teatro que só vai ter vez daqui a 20 anos. (GOMES, 1994, p. 398).

Assim, o escritor viria resgatar toda essa temática de modo mais contundente no período que corresponde à segunda fase de sua produção teatral, a partir de 1959 quando escreve O pagador de promessas, considerado pelo autor e pela crítica como um divisor de águas em sua carreira.

\section{Referências}

ANDRADE, Jorge. A moratória. In: Idem. Marta, a árvore e o relógio. São Paulo: Perspectiva, 1986, p. 117-188.

BENJAMIN, Walter. Que é o teatro épico? Um estudo sobre Brecht. In: Idem. Obras escolhidas vol. I: magia e técnica, arte e política. São Paulo: Brasiliense, 1985, p. 7890.

BRECHT, Bertolt. Poemas 1913-1956. Trad. Paulo César de Souza. São Paulo: Ed. 34, 2007.

COSTA, Iná Camargo. Dias Gomes - um dramaturgo nacional-popular. São Paulo: Editora Unesp, 2017.

GOMES, Dias. Peças da juventude: Pé de Cabra/ Eu acuso o céu / Os cinco fugitivos do Juízo Final. Coordenação Antonio Mercado. Rio de Janeiro: Bertrand Brasil, 1994. MAGALDI, Sábato. Panorama do Teatro Brasileiro. São Paulo: Global Editora, 2004. 
MERCADO, Antonio. Coleção Dias Gomes - Peças da Juventude. In: GOMES, Dias. Peças da juventude: Pé de Cabra/ Eu acuso o céu / Os cinco fugitivos do Juízo Final. Coordenação Antonio Mercado. Rio de Janeiro: Bertrand Brasil, 1994, p. 7-37.

PRADO, Décio de Almeida. O Teatro Moderno Brasileiro. São Paulo: Perspectiva: Editora da Universidade de São Paulo: 1988.

Peças, Pessoas, Personagens. São Paulo: Cia. das Letras,1993, p. 43-44.

ROSENFELD, Anatol. A obra de Dias Gomes. In: Idem. O mito e o herói no moderno teatro brasileiro. São Paulo: Perspectiva, 1996, p. 55-86.

WILLIAMS, Raymond. O teatro como fórum político. In: Idem. Política do modernismo: contra os novos conformistas. Trad. André Glaser. São Paulo: Editora Unesp, 2011, p. 73-92. 